\title{
The Innovation of Human Resource Management in Education to Improve School Quality
}

\author{
Nurochim \\ Syarif Hidayatullah State Islamic University Jakarta, Jl. Ir. H. Djuanda 95, Ciputat, Indnnesia \\ Corresponding e-mail: nurochim@uinjkt.ac.id
}

\begin{abstract}
Human Resource Management education is any effort in the form of policies, activities, considerations intended for human resources in this case educators and school personnel can afford and prosper in working optimally to achieve educational goals. The purpose of this research is to know the human resource management in school to improve its school quality. This study aims to analyze the management of human resources education in Madrasah Aliyah (Islamic School) Darussalam Bogor, using qualitative descriptive analysis. This study uses the qualitative approach, with case study method. The technique of data collection is the interview, observation and literature study also used to improve the data. The results of this research shows that Madrasah Aliyah Darussalam Bogor has done the process of human resource management of education very well. This can be seen from the learning process, school development, teacher competence that are well developed. Headmaster in this school has good leadership and entrepreneurship. He motivates all academic staff to have the best performance. Although this school has limited cost but can give the best service for students.
\end{abstract}

Keywords: human resource management, islamic education, innovation, leadership, entrepreneurship

\section{INTRODUCTION}

Education's long-term orientations are providing the best quality of educational service that suit with stakeholders. This ortientation can reach when school leader can organize professional human resource management. Management human resource academic staff is a district process consisting of planning, organizing, actuating, and controling, performed to determine and accomplished stated objectives by the use of human beings and other resources (Marlina 2015:124). An educational institution need human resource management who have five competencies, namely innovation, best service, extraordinary quality, special skill, productivity (Gates and Langevin, 2013:2). The innovation is a skill to find some thing new or modify something into better forms. The innovation in educational institution should be able to give the best service. The productivity is an indicator for educational institution efectivity. Productivity in educational institution is related to the whole process of structuring and using resources to achieve educational goals effectively and efficiently. The best service for give service for educational stakeholders. The special skill namely pedagogic, social, professional, personal skill is needed for defferenting educational organization with another organization.

Islamic education in Indonesia also known by Madrasah. In Indonesian educational system, Islamic education have an important role. It attains Indonesian educational's goal and also establishes piety value among students. In madrasah, students learn many Islamic lesson like Qur'an Hadits, Fiqh, Akidah Akhlak (moral theology), and history of Islam. Until now, several Indonesian Islamic Education has many problem, especially funding problem, school human resource management, and school quality. Madrasah who have funding problem usually, madrasah who organize by privat institution, this madrasa in the middle and lower 
market share. If they have funding problem, they will have school human resource problem, and this impact is low quality of education.

The innovation in school human resource is needed to improve school quality. Human resoure is important part of school organization, because the human think and organize an school organization. Human establish goal of organizatioan and strategy to achieve school's goal. So, to improve school quality, the first step is improve the quality of school human resource. The innovation in school human resource management begin from the headmaster as school leader. The ideal principal is the principal who has the ability to become a motivator, innovator and administrator and as a supervisor in all kinds of school management activities, therefore the principal must have a good and strong character or personality, understanding and have of management skills. The principals who have conceptual skills always find ways or tricks that can be used to advance the school. Thus, the principal can plan, formulate brilliant ideas so that the school in its development always finds new innovations that are not only beneficial to the development of the school, but can be replicated by other schools. The principal as an educational administrator should be able to manage: (a) teaching, (b) personnel, (c) student affairs, (d) facilities and infrastructure, (e) finances, (f) community relations and (g) service. The common themes associated with the principalship, the exercise of power, relationships with teachers, students and community, and so on (Thomas, 1998,90). The principals sould be demonstrated ability in developing the school vision, setting strategies, building capacity, and establishing a broader network to achieve the benefits of school improvement (Raihani, 2008,481).

The statistical data indicate that teachers' motivation is significantly related to principals' transformational leadership practices, as perceived by teachers. To strengthen teachers' motivation in schools, they should exhibit the individual consideration and intellectual stimulation practices more frequently (Othman And Wanlabeh, 2012,237). Principals of traditional independent schools are invariably allocated by their governing bodies all duties and powers regarding discipline, programmes of study, selection and management of staff, and school activities generally. They are thus in a powerful position within their schools to facilitate effective and efficient responses to legitimate pressures for change, and to recognise and reject meretricious pressures for change (Smith, 1989,9). The school principals sould be held teacher training, for effective management of interpersonal relationship. It is fit with Menon's opinion, to the need for better training and preparation of both school leaders and teachers before their appointments (Menon, 2002,91). The school headmaster also sould be an exemplary school community, the forms of leadership service values in Malaysian school communities as adjudged by exemplary principals and head teachers (Bajunid, 1996,21). The academic administrators in Madrasa were imbued with Islamic leadership principles. The research also showed that servant-leadership approach is preferably used in conjunction with alternative transactional and transformational styles, while the revealed sources of knowledge (Quran and Sunnah) were given the highest priority as sources of developing leadership principles (Ahmad and Ogunsola, 2011,291).

Human resource Management be needed in school organization. Human resource management in education needed to minimize uncertainties around the school. In scientific human resource management arranged design of work and its needed in school organization. In designing job for school personel believe in putting back together (Johnnie, 1993,6). The school personel sould be trained in management. Kozubska $(1987,4)$ says that making teacher more effective managers sould involve the application of five management concepts namely financial management, marketing, educational operations and systems management, strategic management, and human resource management. It's important because teachers must be develop strategic to meet education future challenges. The managers in education in education sectors sould be develop their human organization. The school managers drive teachers participating in school management programs. Fisher $(1987,5)$ argues that the nature of teaching and the imperative of school management affect to teacher's performance and involvement in management. Therefore can be understood that the arrangement of nature of teaching can driven teacher's performance to give the better quality of teaching service. As well as Fisher's argument, Dora Ho $(2009,217)$ said that the role of leadership in creating a culture and procedures for collective participation in staff appraisal is important for human resource management in school setting. It can be concluded that the main person in school human resource management in education is school leader, besause school leader determines the direction of the organization. The major topics within school human resource management are recruiting, employment 
and labour relations (Thompson and Kleiner, 2005,45). The appointment of teachers in schools is that structured panel interviews, with trained panel members, and preferably including an HR professional, would represent best practice (Griever and Hanafis, 2005,20).

\section{METHODS}

This research aim is to know a form of innovation in islamic school's human resource management. This research papper use kualitative methodology. This Data collected by deep interview and observation in Darussalam Islamic High School Bogor. Key informants in this research is headmaster, teacher, and student. Data analyzed with transcribe all the data, organize al the data, give codes to first set of fied notes drawn from obervations, interviews, and document reviews, note personal reflections, sort and sift through the materials to identify similar phrases, relationships between themes, identify these patterns and processes, elaborating a small set of generalizations that cover the consistencies discerned in the database, and examine those generalizations in light of a formalized body of knowledge in the form of theories.

\section{RESULTS AND DISCUSSION}

The educational innovation is an innovation found in education or innovation to solve problems in education. This educational innovation is basically a change or a result of brilliant thinking in the field of education with the characteristics of a novelty or in the form of certain educational practices or form product of a result of thought and also technological that applied through certain stages which is believed and intended to solve various problems concerning education that arise and improve a state of education or any process of certain education activities that currently occur in the community.

The result of the research shows that the process of human resource management of education, Madrasah Aliyah Darussalam has done the managerial and operational process well, so that the learning process and school development and teacher competence can be done well. Headmaster in this school have good leadership and entrepreneurship. He motivates all education staff to have the best performance. Although this school has limited cost, but can give the best service for students. All education staff have good teamwork. School quality as an impact of it, seen from the achievement, both academic and non academic achievements are inscribed by the school. Personnel development, this innovation is in accordance with the personal components such as: promotion system, improving teacher quality, and student disciplinary rules.

The school leader develops trust among teachers by discuss and begin togetherness to solve the school's problem, so all tachers in Madrasa Darussalam involved in every management activity to improve school quality. All teacher driven to give the best service to all students by teach with fun learning environment. One of fun learning in this school is teacher teach with appropriate lesson strategic. The headmaster also identifies source of strees among teachers, and after this the headmaster choose one of solution. The school leader copes with ambiguity about teaching and managerial task. The headmaster arranges funding proposal to financier, furthermore the headmastes motivates the student to organize cup cake business and school coop. The haeadmaster cooperates with business and industry sector to held art performances, and give opportunity to students and all teachers to practice entrepreneurship by holding business bazaar. The principal's actions in realizing his role as an innovator, seen by the headmaster in creating renewal and new ideas for school development. New ideas by the principal include the provision of a multimedia room, the provision of a catering practice room, the principal submits a proposal to the Office of Education to get a large oven, so that the culinary skill program gets the ease in practicing instantly making the cookies.

The principal in the work constructively, carried out by giving direction, encouragement and coaching at the meeting or at every opportunity that exists. Directives made by the principal, when at the time before the meeting, the principal gave a warning and provision for educators who became committee of an activity, in order not to make mistakes. Furthermore, the principal as an innovator, will be reflected by his delegative workings. Delegatif conducted by the principal is by setting the pattern of the right man in the right place in every giving of office to educator. The principal at the time of the meeting also directs, so that the division of tasks tailored to the field of expertise of each personal, in accordance with the duties and functions. Principal as an innovator, also reflected by his integrative way of working. The principal in integrative work is realized by producing activities that are integrated with the vision, mission and objectives of the school. School activities such as industrial work parks, Ramadan fasting schools, 
school art performances, Kartini's day celebrations, culinary production units, field recognition observations are some of the activities that schools undertake to achieve school vision, mission and programs.

The principal as a motivator will be realized by his actions that motivate all the school staff. The forms of motivation are done by the principal during meetings, ceremonies and impose reward and punishment patterns to the school community. Rewards for teachers who get score academic and non academic achievements, and punishment for school staff who attend less, will be given a memo. This is to encourage the school staff to be more discipline and encourage students to get the best achievement. One of the principal's actions as a motivator, is manifested by creating a conducive working space for educators and education personnel. The setting of the school environment for the teachers' room, the principal gives the educator and educational rights with the provision of one person a bench. Thus, all school staff get their rights in the form of a seat in the school. Training professional and managerial held in this school in every early smester, to improve motivation and skill all school staff.

Headmaster in this school has the uniqueness of work and character as follows: (1) The principal has morale and high motivation to develop the ability and expertise of human resources by working hard, smart and sincere; (2) Principal always striving for educators (teachers), employees and learners to feel the maximum welfare of education services in schools; Furthermore, (3) The principal always strives realizing the school's vision and mission, familiarize the administration of humanist religious education and give awareness in behaving as pedagogic creatures. As a learning resource, the principal actively supports activities and daily learning programs by modeling desired behaviors, participating in upgrading, and consistently giving priority to learning problems.

\section{CONCLUSIONS}

The innovation will be realized if there is a change of perception, atmosphere, and meaning. These three things need to be understood by teachers by reflecting themselves, especially in applying meaningful learning. The Principal recruits teachers who have idealism, dedication, and high commitment in performing their duties. These schools recruit intelligent principals in performing their roles as educators, managers, administrative, supervisors, leaders, creative and capable drivers. Optimizing the role of principals will certainly support efforts to improve the quality of education. Placing a principal who dares to acknowledge every actual phenomenon in the field of education with real activity, needs to be done in order to occur consistency between expectations and reality. The principal motivate all teachers to educate students to be an intelligent, good manners, and noble character.

\section{ACKNOWLEDGEMENTS}

The authors wish to thank Faculty of Education Sciences UIN Syarif Hidayatullah Jakarta.

\section{REFERENCES}

Ahmad, K., Ogunsola O. K. (2011). An Empirical Assessment Of Islamic Leadership Principles. International Journal of Commerce and Management, 21(3), 291-318.

Bajunid, I. A., et. all. (1996). Malaysian Educative Leadership: Interim Research Findings. International Journal of Educational Management, 10(2), 21-26.

Dora Ho, C. (2009). Human resource management in Hong Kong preschools: the impact of falling rolls on staffing. International Journal of Educational Management, 23(3), 217-226.

Fisher, C. M. (1987). Teachers, School, and Manager Management. International Journal of Educational Management, 1(1), 5-9.

Gates, S., Langevin, P. (2010). Human capital measures, strategy and performance: HR managers' perceptions. Accounting Auditing and Accountability Journal, 23(1), 111-132.

Grieves, J., Hanafi, P. (2005). Human Resource Management: The Achilles Heel Of School Governance. Employee Relations, 27(1), 20-46.

Johnnie, P. B. (1993). Formal Education: A Paradigm for Human Resource Development in Organizations. International Journal of Educational Management, 7(5), 4-8.

Kozubzka, Joanna. (1987). Master of Educational Management. International Journal of Educational Management, 1(1), 4-4.

Marlina, L. (2015). Manajemen Sumber Daya Manusia (SDM) dalam Pendidikan. Istinbath, XIV, 123-139.

Menon, M. E. (2002). Perceptions of pre-service and inservice teachers regarding the effectiveness of elementary school leadership in Cyprus. International Journal of Educational Management, 16(2), 91-97.

Othman, A., Wanlabeh, N. (2012). Teachers' Perspectives On Leadership Practices And Motivation In Islamic Private Schools, Southern Thailand. Asian Education and Development Studies, 1(3), 237-250. 
Raihani. (2008). An Indonesian Model Of Successful School Leadership. Journal of Educational Administration, 46(4), 481-496.

Smith, L. R. (1989). The Traditional Independent School Principal: Innovator or Inhibitor. Journal of Educational Administration, 27(2), 9-14.

Thomas, A. R. (1998). As They Are Portrayed: Principals In Film. International Journal of Educational Management, 12(2), 90-100.

Thompson, J., Kleiner, B. H. (2005). Effective Human Resource Management Of School Districts. Management Research News, 28(2/3), 42-55. 